\title{
Retraction Note: A deep learning model and machine learning methods for the classification of potential coronavirus treatments on a single human cell
}

\author{
Nour Eldeen M. Khalifa • Mohamed Hamed N. Taha • \\ Gunasekaran Manogaran • Mohamed Loey (D)
}

Published online: 16 August 2021

(C) Springer Nature B.V. 2021

Retraction Note to: J Nanopart Res (2020) 22:313 https://doi.org/10.1007/s11051-020-05041-z

The Editor-in-Chief and the Publisher have retracted this article. The article was accepted as part of a guest-edited special issue in Journal of Nanoparticle Research. Before the special issue was finalized, the Editor-in-Chief detected problems with editorial handling and peer review and

The online version of the original article can be found at https://doi.org/10.1007/s11051-020-05041-z

N. E. M. Khalifa • M. H. N. Taha

Information Technology (IT) Department, Cairo University, 15613, Cairo, Egypt

\section{N. E. M. Khalifa}

e-mail: nourmanmoud@cu.edu.eg

M. H. N. Taha

e-mail: m_taha@cu.edu.eg

G. Manogaran

University of California, CADavis, USA

e-mail: gmanogaran@ieee.org

G. Manogaran

College of Information and Electrical Engineering, Asia

University, Taichung, Taiwan

M. Loey $(\bowtie)$

Department of Computer Science, Faculty of Computers and Artificial Intelligence, Banha University, 13518 Banha, Egypt

e-mail: mohamed.loey@fci.bu.edu.eg decided not to proceed with the special issue and retracted all the published articles [1].

Post publication peer review found that this article is out of scope for the journal, which focuses on original contributions on nanoscale phenomena and processes, and does not meet the standards required by the journal.

None of the authors agree to this retraction.

\section{Reference}

1. Pinna N, Clavel G, Roco MC (2020) The journal of nanoparticle research victim of an organized rogue editor network! J Nanopart Res 22:376. https://doi.org/10.1007/s11051-02005094-0

Publisher's note Springer Nature remains neutral with regard to jurisdictional claims in published maps and institutional affiliations. 